\title{
CORRELATION BETWEEN BLOOD GLUCOSE LEVEL AND THINKING CONCENTRATION
}

\author{
Putri Itonami Gaol Marbun and Tengku Helvi Mardiani \\ Department of Biochemistry, Faculty of Medicine, Universitas Sumatera Utara, Medan
}

\begin{abstract}
ABSTRAK
Fungsi kognisi secara spesifik mengenai konsentrasi berpikir masih belum banyak diteliti. Pandangan masyarakat menunjukkan bahwa glukosa berperan dalam kualitas berpikir. Beberapa studi menunjukkan glukosa mempengaruhi kualitas memori spesifik tetapi tidak pada berpikir kompleks. Penelitian ini bertujuan untuk mengetahui hubungan kadar gula darah dengan konsentrasi berpikir di saat sebelum makan (preprandial), sesudah makan (postprandial), dan efek peningkatan kadar gula darah pada konsentrasi berpikir. Subjek yang memenuhi syarat penelitian direkrut sampai dengan jumlah empat puluh enam orang dan diikuti selama tiga puluh menit. Kadar Gula Darah diukur pada awal menggunakan glucose meter, konsentrasi berpikir diukur pada awal menggunakan trail making test, dan dibandingkan setelah makan pada menit ketiga puluh. Analisis deskriptif menunjukkan kadar gula darah preprandial pada seluruh subjek adalah 55-119 mg/dl dengan rata-rata 98,2 mg/dl. Kadar gula darah postprandial pada seluruh subjek penelitian adalah 103-171 mg/dl dengan rata-rata 134,5 mg/dl. Konsentrasi berpikir preprandial pada seluruh subjek penelitian adalah 28-93 detik dengan rata-rata 56,42 detik. Konsentrasi berpikir postprandial pada seluruh subjek penelitian adalah 24-73 detik dengan rata-rata 47,5 detik. Analisis korelatif Pearson menunjukkan tidak terdapat hubungan antara kadar gula darah preprandial dengan konsentrasi berpikir $(p=0,556)$, kadar gula darah postprandial dengan konsentrasi berpikir $(p=0,533)$, dan peningkatan kadar gula darah dengan konsentrasi berpikir $(p=0,928)$. Simpulan, tidak ada korelasi antara kadar gula darah dengan konsentrasi berpikir. (FMI 2016;52:214-218)
\end{abstract}

Kata kunci: kadar gula darah, konsentrasi berpikir, preprandial, dan postprandial.

\begin{abstract}
Cognition function specifically about thinking concentration has not much yet been studied. Society view shown that glucose has role thinking quality. Few studies shown that glucose has role in specific memory quality but not in complex thinking. This study purpose to see correlation between blood glucose level with thinking concentration before eating (preprandial), after eating (postprandial), and the effect of blood glucose rise on thinking concentration. Subjects that accomplished study's requirement were recruited until forty six people and were followed within thirty minutes. Blood Glucose level was measured by glucose meter at initial admission, thinking concentration were measured with trail making test at initial admission, and compared after eating on the thirtieth minute. Descriptive analytic shown that preprandial blood glucose level in all subject is $55-119 \mathrm{mg} / \mathrm{dl}$ with $98.2 \mathrm{mg} / \mathrm{dl}$ mean. Postprandial blood glucose level in all subject is 103-171 mg/dl with $134.5 \mathrm{mg} / \mathrm{dl}$ mean. Preprandial thinking concentration in all subject is $28-93$ seconds with 56.42 seconds mean. Postprandial thinking concentration in all subject is $24-73$ seconds with 47.5 seconds mean. Correlation analysis showed that no significance between preprandial blood glucose level and thinking concentration $(p=0.556)$, postprandial blood glucose level and thinking concentration $(p=0.533)$, and increase in blood glucose and thinking concentration $(p=0.928)$. In conclusion there is no significant correlation between blood glucose level and thinking concentration. (FMI 2016;52:214-218)
\end{abstract}

Keywords: blood glucose level, thinking concentration, preprandial, and postprandial.

Correspondence: Putri Itonami Gaol Marbun, Faculty of Medicine, Universitas Sumatera Utara, Jalan dr. T. Mansyur no. 5, Medan 20155, Indonesia. Phone: +6281269743311. e-mail: putri.marbun@ gmail.com.

\section{INTRODUCTION}

Human is the most dominating factor of all system where human were part of the system itself. Human's thinking behavior and needs are the main factor of power that underlie almost all human activities in regulating machine performance and socialization (Wang 2008). In many human disciplinary, almost all difficult problems that must be handled have the same roots that are in understanding natural intelligence mechanism and cognition part from human factor
(Eagly \& Chaiken 1992). Thinking Proses is a way when human combine all ideas and associations that made human's intellection. Sensorium and cognition is addressed to assess organic brain function, intelligence part, abstract thinking capacity, approaching level, and judgment (Rediyani 2013). Concentration or attention is a way to direct mental activities on certain experience. Attention disturbance include inability to centralize attention, maintain attention, or divert attention (Dharmono 2013). 
Most tissues have certain level for glucose. In brain, this need is highly important. Glucose supply is needed mainly for nerve system and erythrocytes. Failure of gluconeogenesis usually fatal. Hypoglycemia can cause brain dysfunction, which leads to coma and death (Bender \& Mayes 2015). Blood glucose is glucose in bloodstream that easily pass blood brain barrier in brain, because brain cannot store glucose, it needs constant supply of glucose to be well-functioned. Deficit of glucose supply to brain can cause bad consequences to brain function (Bander \& Mayes 2015). Glucose is the final product of carbohydrate metabolism and is the main energy source for living organism, that function is controlled by insulin (Dorland 2007). Normal blood glucose after more than eight our fasting in human is $70-100 \mathrm{mg} / \mathrm{dl}$, random is below $125 \mathrm{mg} / \mathrm{dl}$, and two hours after eating is below $180 \mathrm{mg} / \mathrm{dl}$ (American Diabetes Association 2014).

Studies showed there is connection between glucose and cognition function. Benton in 1998 showed there is connection between blood glucose levels with human cognition. Donohoe and Benton in 1999 stated cognition function susceptible to blood glucose level. Cognition function itself is a combination from consciousness, orientation, memory, concentration, abstract thinking, and intelligence ability (Rediyani 2013).Cognition function itself was affected by biological and physiological factors. Those are habituation, attitude, word, and biological factors like hormone, heredity, and eating behavior (Elvira 2013). Based on that, the importance of human thinking ability is affected by many factors. One of them is nutrition that is glucose. Studies about human cognition specifically in thinking concentration is still poorly investigated. This study aims to see the relationship between blood glucose levels with thinking concentration in healthy normal men.

\section{MATERIALS AND METHODS}

This type of research is analytic observational prospective cohort design. This research was conducted in the faculty of medicine Universitas Sumatera Utara during August 2015. Affordable population is male college students who underwent studies in medicine faculty of Universitas Sumatera Utara. Forty six samples are counted by using correlation sampel formula considering 5\% first type of error and 5\% second type of error with 0.5 assigned correlation coefficient. Purposive sampling method of consecutive sampling, met the inclusion criteria that aged between 20-30 year old, body mass index 18.4-24.9 kg/m2, and willing to comply with study procedures by signing the informed consent. Exclusion criteria include doing heavy exercise in last one week, heavy alcohol consumption, smoking, having diabetes history, and consumption of blood glucose regulating drugs.

Subjects are requested to fasting in eight hours. In the morning after fasting, blood glucose level and thinking concentration is measured in silent and comfortable room. Subjects then were given bread, strawberry jam, honey, and orange juice with total 225 calorie, 6.7 grams protein, 4.6 grams fat, 51.4 grams carbohydrate, and 1.3 grams fiber to be eaten. After thirty minutes, blood glucose and thinking concentration were measured again. Then the results were compared. Measurement were done by college who have been trained to do the measurement. Blood glucose level is measured by blood glucose meter, using the oxidation mechanism with $\mathrm{mg} / \mathrm{dl}$ as unit measurement. Thinking concentration is measure by trail making test $\mathrm{B}$, subject are told to connect number and letter in consecutive manner without failing, time in seconds to finish the task is used as the unit measurement.

\section{RESULTS}

Total sample in this study, analyzed are 46 people with range of ages from 20-21 years (mean $20.83+0.38$ years). The mean level of blood glucose level in this study is $14.7 \mathrm{mg} / \mathrm{dl}+14.7 \mathrm{mg} / \mathrm{dl}$ preprandial and 134.5 $\mathrm{mg} / \mathrm{dl}+15.6 \mathrm{mg} / \mathrm{dl}$ postprandial. Mean level of thinking concentration in this study is 56.42 seconds +13.94 seconds preprandial and 47.5 seconds +11.64 seconds postprandial. Analysis of correlation by Pearson method showed that there were no significant correlation between preprandial blood glucose level with thinking concentration $(\mathrm{r}=0.089, \mathrm{p}=0.533)$. There is no significant correlation between thirty minutes after eating 252 calorie blood glucose level and thinking concentration $(r=0.094, p=0.533)$. There is no significant in rising in blood glucose with thinking concentration $(r=0.14, p=0.928)$.

\section{DISCUSSION}

Mean blood glucose level in this study preprandial is $98.2 \mathrm{mg} / \mathrm{dl}+14.7 \mathrm{mg} / \mathrm{dl}$. Based on Republic Indonesia's Health Department, normal blood glucose level after fasting eight hours is $80-110 \mathrm{mg} / \mathrm{dl}$. Three subjects have blood glucose level more than $110 \mathrm{mg} / \mathrm{dl}$. This indicated that subjects may have disturbance in body glucose regulation without any clinical significance. Subjects ate 225 calorie high glycemic fast absorption food with 6.7 grams protein, 4.6 grams fat, 51.4 grams carbohydrate, and 1.3 grams fiber. This study showed $4 \%$ subjects have blood glucose level $<110 \mathrm{mg} / \mathrm{dl}, 9 \%>160 \mathrm{mg} / \mathrm{dl}$, and $87 \%$ 110-160 mg/dl. Mean increase in blood 
glucose level is $36.3 \mathrm{mg} / \mathrm{dl}+15.3 \mathrm{mg} / \mathrm{dl}$ with mean blood glucose attained is $134.5 \mathrm{mg} / \mathrm{dl}+15.6 \mathrm{mg} / \mathrm{dl}$. Based on Republic Indonesia's Health Department, blood glucose level after eating is $110-160 \mathrm{mg} / \mathrm{dl}$. This study showed most of subject have normal postprandial blood glucose.

Freckman et al (2007) studied with giving same food consumption and achieved mean increase $55.8 \mathrm{mg} / \mathrm{dl} \mathrm{+}$ $21.7 \mathrm{mg} / \mathrm{dl}$ with mean blood glucose achieved 137.2 $\mathrm{mg} / \mathrm{dl}+21.1 \mathrm{mg} / \mathrm{dl}$. His study used Continuous Glucose Profile test. This showed there is difference in escalation blood glucose level in this study, all subjects were Asian, with his study where all subjects were Caucasian, even though blood glucose level achieved were not too much different. This show that there is body regulation to achieve certain blood glucose level after food consumption. Gorht-Marnat, Gary (2013) showed normal performance level trail making test B is 0-85 seconds; mild damage, 86-120 seconds; and heavy damage, $>121$ seconds. In this study subjects have completed the task in $56.42+13.94$ seconds mean after fasting and $47.5+11.64$ seconds mean. This showed that subjects have normal thinking concentration even though there is one subject finished in 93 seconds showed it has mild thinking concentration damage in prepandial test but become better in postprandial test.

\section{Preprandial blood glucose level and thinking concentration}

Based on correlation analysis, this study showed there is no significant correlation between blood glucose level and thinking concentration. This is because there is body regulation to brain is maintain constantly. In the time of hunger, brain after some time gained ability to use ketones body to produce ATP. In the first week of famine, there is strong increase in enzyme activity needed for this in brain. Ketones body degradation in central nerve system spare glucose and because of that reduce protein breakdown in muscle that maintain gluconeogenesis in heart during famine. After some weeks, broad muscle degradation is decreasing until one-third initial amount (Koolman \& Roehm 2007). See Figure 1.

\section{Postprandial blood glucose level and thinking concentration}

Based on correlation analysis, this study showed there is no significance correlation in postprandial blood glucose level with thinking concentration. This is because there are many factor regulate thinking concentration, those were physiological factors like habituation, attitude, word, and biological factors like hormone, heredity, and eating behavior (Elvira 2013).

\section{Escalation of blood glucose level and thinking concentration}

Based on correlation analysis, this study showed there is no significance correlation in escalation of blood glucose with thinking concentration. This is may because brain has fixed consumption of glucose supply. Benton and Parker in 1998, found there is correlation between spatial memory task $(r=5.42, p=0.03)$ but there is no correlation in word recall performance $(\mathrm{p}>0.05)$. This showed some mechanism in brain that is affected by glucose and some are not. Some of subjects in this study showed decrease in thinking concentration after escalation of blood glucose, this showed there is increase in parasympathetic reflex that cause blood pumping were directed to gastrointestinal system. Hyperglycemic condition can also cause rise in blood viscosity that make decrease flow to the brain and

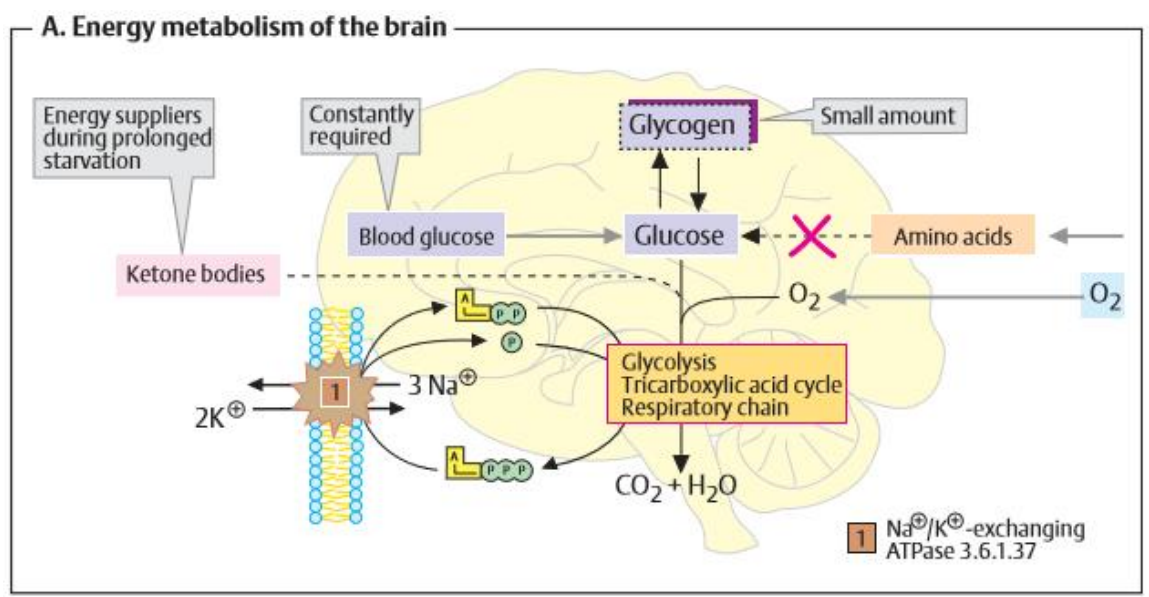

Figure 1. Glucose metabolism in brain 
person can experience reduction of cognition function just like founded in hypoglycemic condition (Nelson \& Cox 2013).

Gold in 1995 found there is connection between blood glucose level and memory in rat and in elderly people with Alzheimer. Craft, S., Murphy, C. and Wemstrom, $\mathrm{J}$. in 1994 found there is no connection between blood glucose level and cognition in complex memory. This study also found there is no significant correlation between blood glucose level and thinking concentration. This showed that blood glucose have little or no effect in complex brain function but have effect in simple brain function, mainly in restoring memory. Then, in normal people blood glucose regulation were functioned normally and can compensate effect in the decrease of blood level, so low blood glucose in fasting and high blood glucose level in after eating in normal range does not affect brain performance (Koolman \& Roehm 2007).

\section{CONCLUSION}

There is no relationship of preprandial blood glucose level with thinking concentration in normal healthy man; there is no relationship of postprandial blood glucose level with thinking concentration; there is no relationship of escalation in blood glucose level with thinking concentration.

\section{REFERENCES}

American Diabetes Association (2015). Checking your Blood Glucose. Available from:http://www.diabetes. org/living-with-diabetes/treatment-and-care/bloodglucose-control/checking-your-blood-glucose.html. Accessed May 30, 2015.

Baehr, M. \& Frotshcer, M. (2012). Duus' Topical Diagnosis in Neurology Anatomy, Physiology, Signs, and Symptoms 5th edition, Thieme, New York.

Bender, David A. \& Mayes, P. A. (2015), Carbohydrate and Physiological Significance. In Rodwell, V. W., Bender, D., Botham, K. M., Kennelly, Weil, P. A.. eds. Harper's Illustrated Biochemistry, 30th Edition. Singapore: Mc. Graw-Hill. 152-160.

Benton D. \& Parker P. Y. (1998). Breakfast, Blood Glucose, and Cognition. American Journal Clinical Nutrition, vol 67, pp. 772-778. Available from http://ajcn.nutrition.org/content/67/4/772S.full.pdf. Accessed May 27, 2015.

Botham, K. M. \& Mayes, P. A. (2015). Bioenergetic. In: Rodwell, V. W., Bender, D., Botham, K. M., Kennelly, Weil, P. A., eds. Harper's Illustrated
Biochemistry, 30th Edition. Singapore: Mc. GrawHill. 115-116 \& 132.

Bromley, C. (2009). Growing up in Scotland: The Impackt of Children's Early Activities on Cognitive Development. Scottish Centre of Social Research, Maret, 2009. Available from www.gov.scot/ Publication/2009/03/16101519/11. Accessed May 29, 2015.

Cahill L. \& Alkire M. T. (2003). Epinephriene enhancement of Human Memory Consolidation: Interaction with Arousal at Encoding. Neurobiology of Learning and Memory, vol. 79, pp.194-198. Available from http://www.ufrgs.br/ppgneuro/artigos/cahill_memory_ epinephrine2003.pdf. Accessed June 1, 2015.

Dahlan, M. S. (2010). Membuat Proposal Penelitian Bidang Kedokteran dan Kesehatan edisi 2. Jakarta: Sagung Seto.

Dahlan, M. S., (2010). Besar Sampel dan Cara Pengambilan Sampel edisi 3. Jakarta: Salemba Medika.

Dharmono S. (2013). Tanda dan Gejala Klinis Psikiatrik. In: Elvira S. D. \& Hadisukanto G., eds. Buku Ajar Psikiatrik. Jakarta: Badan Penerbit FK UI, 62-72.

Donohoe R. T \& Benton D. (1999). Cognitive Functioning is Susceptible to the Level of Blood Glucose. Psychopharmacology, vol 145, pp. 378-385. Available from http://ajcn.nutrition.org. Accessed April 10, 2015.

Dorland's illustrated medical dictionary (31st ed.). (2007). PA: Saunders, Philadelphia.

Eagly, A. H., \& Chaiken, S., (1992), 'The Psychology of Attitudes. San Diego, CA: Harcourt Brace.

Elvira S. D. (2013). Psikodinamik. In: Elvira S. D. \& Hadisukanto G., eds. Buku Ajar Psikiatrik. Jakarta: Badan Penerbit FK UI, 47-61.

Freckmann, G., et al (2007). Continuous Glucose Profiles in Healthy Subjects under Everyday Life Conditions and after Different Meals. Journal of Diabetes Science and Technology, vol. 1, issue 5, pp. 695-703. Available from http://www.ncbi.nlm.nih. gov/pmc/articles/PMC2769652. Accessed March 29, 2015.

Gold, P. E. (1995). Role of Glucose in Regulating the Brain and Cognition. American Journal Clinical Nutriotion, vol 61, pp. 987-995. Available from http://ajcn.nutrition.org/content/61/4/987S.full.pdf. Accessed April 10, 2015.

Groth-Marnat, G. (2003). Handbook of Psychological References and Indexes. USA: John Wiley \& Sons, Inc.

Koolman, J. \& Roehm K. H. (2007).Color Atlas of Biochemistry, Stuttgart, Germany: Thieme.

Matlin, M., W., (2009), Cognitive Psychology 7th edition, John Wiley \& Sons, New York. 
Moore, K. L., \& Agur, A. M. R. (2007). Essential Clinical Anatomy 3rd edition. New York: Lippincot Williams \& Wilkins.

Nelson, D. L., \& Cox, M. M. (2013). Lehninger's Principles of Biochemistry 5th Edition. 239-247.

Rediyani P. (2013). Wawancara dan Pemeriksaan Psikiatrik. In: Elvira S. D. \& Hadisukanto G., eds. Buku Ajar Psikiatrik. Jakarta: Badan Penerbit FK UI, 47-61.
Wang, Y. 2008. On Cognitive Properties of Human Factors and Error Models in Engineering and Socialization. International Journal of Cognitive Informatics and Natural Intelligence, vol. 2, issue 4, pp. 70-84. Available from http://www.ucalgary.ca/ icic/files/icic/76-IJCINI-2406-HumanTraits.pdf. Accessed May 10, 2015. 